\title{
Experiencing Digital Works through the Development of Online Inventory Management System for BuLSU Supply Office
}

\author{
Mayleen Dorcas B. Castro ${ }^{1}$ \\ ${ }^{1}$ College of Information \& Communications Technology, Bulacan State University, City of Malolos, Bulacan, \\ Philippines, 3000
}

\begin{abstract}
Background/Objectives: Inventory management is looked upon as a day to day operation concern. The major function of inventory management system is the supervision of supplies and materials throughout the defined acquisitions from procurement to consumption point in an organization. Methods/Statistical analysis: In this research, the proponent concern is to design and develop an Online Inventory Management Systems for Bulacan State University (BulSU) Supply Office including all its satellite campuses around Bulacan, Philippines. Findings: The proponent considered several system functionalities which were incorporated into the developed system like creation of user account for the administrator and different users; automated inventory management systems; managing the records easier, faster and more secured; and generation of different reports. Improvements/Applications: Only the administrator and registered user can access the system but only the administrator can manipulate all the features in the system.
\end{abstract}

\section{Index Terms}

Inventory, Inventory Management System, Online Inventory, Supply Office

\footnotetext{
Corresponding author : Mayleen Dorcas B. Castro mayleen.castro@bulsu.edu.ph

- Manuscript received November 7, 2017.

- Revised November 20, 2017; Accepted December 2, 2017.

- Date of publication December 31, 2017.

(c) The Academic Society of Convergence Science Inc.

2546-1583 $\odot 2017$ IJEMR. Personal use is permitted, but republication/redistribution requires IJEMR permission.
} 


\section{INTRODUCTION}

The computer is one of the most powerful innovations in human history. With the use of computers, people are suddenly able to perform a staggering amount of task and computation easily.

Like an Inventory Management which concerns with the identification and tracking of Information Services (IS) hardware and software assets [1].

Up-to-date information about data processing resources through the creation and archiving of records in a centralized repository is very crucial. Financial and service records for all components in the inventory should be monitored and maintained.

Inventory is defined as a stock of goods that is maintained by a business in expectation of some future demand. [2] The quantity to which inventory must fall in order to mention that an order must be placed to restock an item. [3] Inventory management is the continuing process of planning, organizing and controlling inventory that aims at minimizing the investment in inventory while balancing the supply and demand. [4]

The Supply Office of Bulacan State University is in charge of supplying items/equipment to different Colleges in the University including satellite campuses. One problem that the office is experiencing is dealing with monitoring of items and equipment that is distributed to different colleges and departments. Item and equipment delivered are individually recorded manually resulting to bulk of paper works and documentation. Another problem is generating necessary reports because they have to consolidate all the records and manually check each record one by one.

The proponent conducted interviews to gather important data in formulating and conceptualizing a system which could be the solution to the said problem. User requirements were carefully observed and analyzed. Using unified model language (UML) like Use Case Diagram, data flow diagrams, and other business modeling, the proponent were able to get all the details that is needed to determine the scope of the system. [5]

Online Inventory Management System for BuLSU Supply Office is a web-based system that is designed to make the inventory transaction more efficient and effective which can be deployed online or using intranet. The goal is to make each transaction faster and easier which lessen the use of manual recording which affects productivity. The Supply Office will be able to monitor and update all the inventory with less time and effort. The system includes adding and retrieving of records with security features. Room and property custodians of different Colleges and other departments just need to access their account thru online using their specified username and password.

\section{A. General Objective}

The main objective of this study is to design and develop an Online Inventory Management Systems for Bulacan State University Supply Office.

\section{B. Specific Objectives}

For the development of the project, specific objectives were considered:

1. To identify the information requirements in the existing system.

2. To identify the problems encountered using the existing system.

3. To integrate functionalities like:

3.1 Admin account;

3.2 Creation of user account for different room and property custodians of the University.

3.3 To adding, editing and retrieval of items/equipment records.

3.4 Checking and assigning number of items and equipment's.

3.5 Monitoring of acquired items, equipment and property.

3.6 Report generation.

4. To identify the information requirements needed online.

5. To determine appropriate security and control measures needed for online inventory management systems.

6. To determine the acceptability and benefits of an online inventory management systems.

\section{Significance of the Study}

The developed Online Inventory Management System for BuLSU Supply Office can be used as a practical tool in managing the University's Supply Office. The study also aims to provide convenience on the part of the administrator as well as the supply office staffs.

Developing a functional, accurate, user-friendly, reliable and secured management through the web will surely benefited the following:

BulSU Supply Office. This research will provide a systematic and efficient inventory management systems which will serve as an effective tool to minimize the time consumed in the process of monitoring the different items/equipment per college. The automation will surely lessen the time and effort spent by the staff for the preparation of reports.

It gave the supply office to communicate with other colleges and department through this online system.

Supply Office Staffs. The system improved the work of the staffs especially in terms of information management. The system provided easier and faster 
way of adding information into the system in terms of monitoring and inventory.

Room and Property Custodians. Through the developed system, all the room and property custodians of the different Colleges would have a well-organized inventory records that is more accurate and reliable. And they can get a faster result of requisitions of their items/equipment.

Future Researchers. The study served as guide for future researchers in conducting the same research and developing an online inventory management system.

\section{Scope and Delimitations of the Study}

The main purpose of this study is to design and develop an "Online Inventory Management Systems for Bulacan State University Supply Office”.

The proponent considered several system functionalities which were incorporated into the developed system as follows: (a) user account for the administrator and users; (b) automated inventory management systems; (c) manage the records easier, faster and more secured; and (d) report generation.

In designing and developing the system, system requirements and hardware requirements were also considered. And for the analysis of the system Agile Model was used as software development method which started in planning, requirement analysis, designing, building and testing.

The level of acceptability of the developed system was measured using the following criterions: functionality; accuracy; reliability; userfriendliness; and security.

For the limitation of the study, only the administrator can create user account that can access the system, however, only the administrator can manipulate all the features of the system.

\section{RESEARCH METHOD}

The Systems Development Life Cycle (SDLC) is a set of activities that the developer use to build an information system. It is the overall process of developing, implementing, and retiring information systems through a multistep process from initiation, analysis, design, implementation, and maintenance to disposal [6]. SDLC is a model of a detailed plan on how to develop and implement the software. It is said that SDLC is a complete plan outlining how the software will start and end from its function.

One of its development models is the Agile model. Agile model is a combination of iterative and incremental process models that focus on process adaptability and customer satisfaction by rapid delivery of working software product [7].

In using Agile model, it is believed that every project needs to be handled differently and the existing methods need to be tailored to best suit the project requirements. In agile the tasks are divided to time boxes (small time frames) to deliver specific features for a release. It has five phases from planning, requirement analysis, designing, building and testing. Iterative approach is taken and working software build is delivered after each iteration. Each build is incremental in terms of features; the final build holds all the features required by the client.

\section{Planning}

The planning phase is the most critical step in completing software development. The proponent carefully planned, particularly in the early stages of developing the project through coordination to the BulSU Supply Office administration concerning the different processes and procedure of inventory and monitoring which will be incorporated into the system to manage project risks effectively. The depth and formality of project plans should be commensurate with the characteristics and risks of the BulSU online inventory management system. [8]

In this stage, planning refine the information gathered during the initiation phase by further identifying the specific activities, processes and resources required to complete the project.

\section{Design Phase}

The design phase involves converting the informational, functional, and network requirements identified during the initiation and planning phases into unified design specifications that the proponent used to script programs during the development phase. [9]

As used in this study, program designs are constructed in various ways. Using a top-down approach, the proponent first identify and link major and minor program components and interfaces, then expand design layouts as they identify and link smaller subsystems and connections.

\section{Requirements Analysis}

The proponent in this phase considered different operational requirements in completing and developing the system. First, all the user requirements were considered and integrated in the system. Hardware and software specifications are also part of requirements analysis.

\section{Building}

The building phase involves converting design specifications into executable programs.

In this stage, effective development standards include requirements that the proponent design specifications before programming begins. The procedures help understand the program designs and functional requirements. 
In developing the BulSU Supply Office inventory management system, system documentation include system descriptions which provide narrative explanations of operating environments and the interrelated input, processing, and output functions of integrated application systems.

Part of the system documentation includes system flowcharts and models that identify the source and type of input information, processing and control actions (automated and manual), and the nature and location of output information.

\section{Testing}

The testing phase requires organizations to complete various tests to ensure the accuracy of programmed code, the inclusion of expected functionality, and the interoperability of applications and other network components. Thorough testing is critical to ensuring systems meet organizational and end-user requirements.

The typically perform tests is either from a topdown or bottom-up approach. A bottom-up approach tests the smaller components first and progressively adds and tests additional components and systems. While top-down approach tests the major components and connections and progressively tests smaller components and connections. The progression and definitions of completed tests vary between organizations.

Bottom-up tests often begin with functional (requirements based) testing. Functional tests should ensure that expected functional, security, and internal control features are present and operating properly. Testing complete the integration and end-to-end testing to ensure application and system components interact properly. Users then conduct acceptance tests to ensure systems meet defined acceptance criteria.

The project will be tested to check if the project meets its objective but if the project did not satisfy the objectives debugging will take place.

\section{A. Conceptual Framework}

Fig. 1 is the conceptual framework which presents the process of the system development. The study was presented using the three dimensions of conceptual paradigm: input, process and output. [10]

The first frame is the Input stage which involved the user requirements like terms, equipment and property records of the University which are needed in the development of the system.

System requirements were also considered which include the hardware requirements and software specifications needed to develop the system. Related literature, related studies, internet articles and online researches were also reviewed.

\begin{tabular}{|c|c|c|}
\hline INPUT & PROCESS & OUTPUT \\
\hline $\begin{array}{l}\text { Part I: Development } \\
\text { of the System } \\
\text { - User Requirements } \\
\text { - Inventory items, } \\
\text { equipment and } \\
\text { properties } \\
\text { - Room Custodian } \\
\text { Profile } \\
\text { - System requirements } \\
\text { - Review of related } \\
\text { literature and } \\
\text { studies } \\
\text { Part Il: Assessment of } \\
\text { the Developed } \\
\text { System in terms of } \\
\text { the following } \\
\text { criterions: } \\
\text { - functionality; } \\
\text { - accuracy; } \\
\text { - reliability; } \\
\text { - user-friendliness; } \\
\text { - security. }\end{array}$ & $\begin{array}{l}\begin{array}{l}\text { Part I: System } \\
\text { Development } \\
\quad \text { Model }\end{array} \\
\checkmark \text { AGILE MODEL } \\
\text { - Planning } \\
\text { - Requirement } \\
\text { analysis } \\
\text { - Designing } \\
\text { - Building and } \\
\text { - Testing } \\
\text { Part II } \\
\checkmark \text { Data Gathering } \\
\checkmark \text { Survey } \\
\text { Questionnaire/ } \\
\text { Interview Guide } \\
\checkmark \text { Analysis and } \\
\text { Interpretation } \\
\text { of the Result }\end{array}$ & $\begin{array}{l}\text { Experiencing } \\
\text { Digital Works } \\
\text { through the } \\
\text { Development of } \\
\text { Online } \\
\text { Inventory } \\
\text { Management } \\
\text { System for } \\
\text { BuLSU Supply } \\
\text { Office }\end{array}$ \\
\hline
\end{tabular}

Fig.1. Conceptual Process Of The System Development

The second frame is the Process stage. In this study, the proponent adopted the Agile Model which is a conceptual model used in project management that describes the stages involved in an information system development project, from an initial feasibility study through maintenance of the completed application.

Data gathering, distribution of survey questionnaire/ interview guide, analysis and interpretation of the result are part of the process of completing the research.

For the Output stage, this is the developed system the "Online Inventory Management Systems for Bulacan State University Supply Office".

\section{B. System Overview}

The system enables the Supply Office to facilitate better monitoring of all the equipment and properties inventory records. It can help the office to manage and make every transaction fast accurately. It provides solution to access critical information, such as inventory availability and quantity on hand. The system enables the system-administrative to update the number of stock during the time of delivery. The system-administrative can also assign item to the university colleges and departments as well as school extensions, which is called Property Acknowledgement. The system-administrative can trace who holds the item through the use of the system. Colleges, Department, offices and satellite 
campuses can apply for Annual Procurement Plan. The system can generate inventory reports such as Item Records, College/Department List, User List, Supplier List, Annual Procurement Plan, Property Acknowledgement, Condemn Items, and Annual Item List. It can display reports in a browser using HTML, and can be exported to Adobe PDF or Microsoft Excel file format.

The user must have one of the following access privilege levels to use the system:

Administrator - has the rights to create, update, and delete records of items, users, positions, college/department, campus, and supplier. Can also backup and restore database. Administrator is allowed to review annual procurement application and/or item requisition. Can acknowledge items to dean/directors and can generate report.

Supply Office Staff - is allowed to review annual procurement application and/or item requisition. Can acknowledge item to dean/directors and can generate report. Supply Office Staff can only access item tab, college/department tab, campus tab and supplier tab in tools and settings menu.

Read/Write Users (Room and Property Custodians) - can submit annual procurement application and/or item requisition. Can confirm reviewed annual procurement plan application. $\mathrm{Read} /$ write user is capable of monitoring items/equipment on hand and can generate report (optional).

Fig. 2 shows the online accessing of room and property custodians using their username and password.

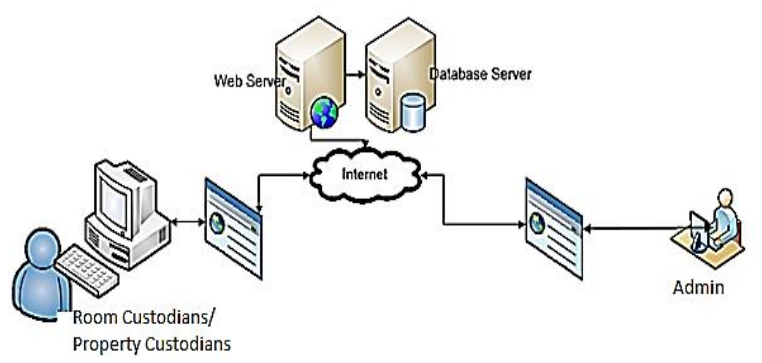

Fig. 2. Online Access In The Online Inventory Management System For Bulsu Supply Office

The administrator of the system is responsible for the content management of the system. All the data and information are stored in a dedicated server.

\section{The Developed System}

This section displays screen shots of the major process of the system. Justifications are also stated.

Inventory Monitoring Details is designed for searching items/equipment and faculty. Search result will be displayed whenever the user typed in a keyword that will match the records. Item search will display item name, total quantity, and stock remaining while faculty search will display faculty name, position, and college name.

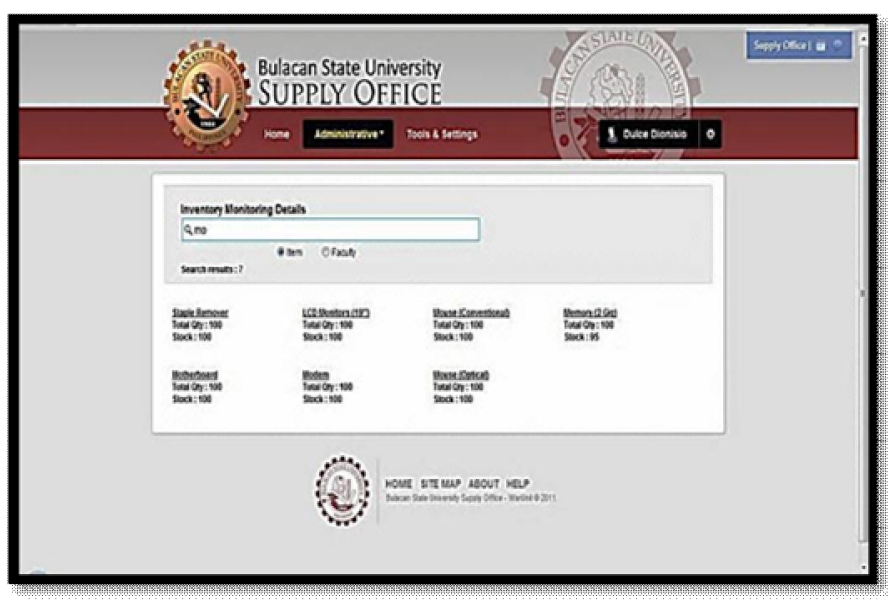

Fig. 3. Inventory Monitoring Details

Reports Summary is part of the system where annual report and list of condemn items are generated. Typing in preferred year or date and search result will be displayed.

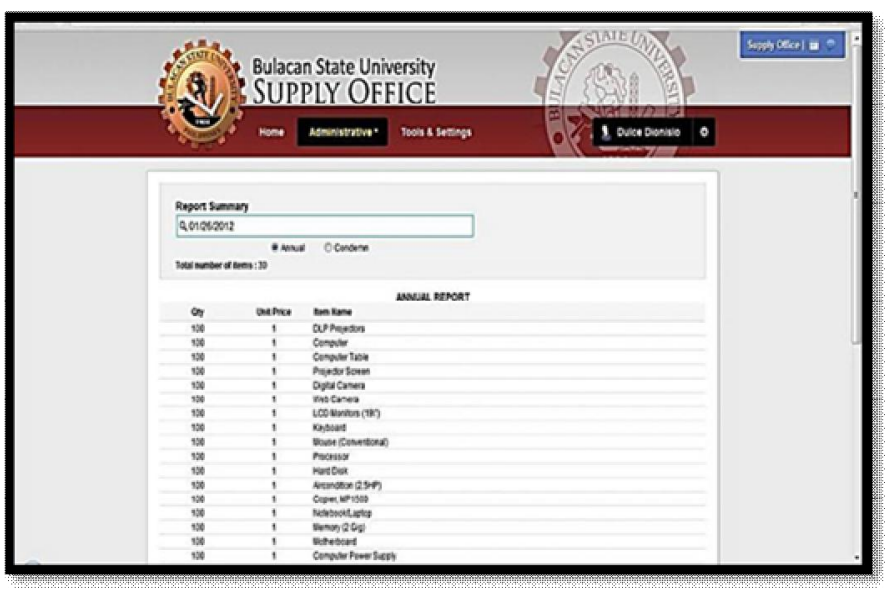

Fig. 4. Reports Summary

Administrator can view the list of all annual procurement plan of the colleges and department. Item/equipment for the school year is delivered quarterly by the supply office. Notification is sent to the dean/director of the College if the application is confirmed.

\section{RESEARCH RESULT}

The data analysis was generally descriptive and quantitative. For the results presentation, analysis and interpretation of data, the following statistical tools were utilized: (1) frequency and percentage distribution in identifying the classification of the 
respondents; and (2) weighted mean in determining the level of the system's acceptability concerning the different system criterions.

To facilitate the interpretation of the weight mean score of the responses, the upper and the lower limit of scale was adopted using the 5-point Likert Scale.

NUMERICAL RATING DESCRIPTIVE INTERPRETATION

\begin{tabular}{lll}
4.60 & 5.00 & Strongly Agree \\
\hline 3.60 & 4.59 & Agree \\
\hline 2.60 & 3.59 & Undecided \\
\hline 1.60 & 2.59 & Disagree \\
\hline 1.0 & 1.59 & Strongly Disagree
\end{tabular}

The primary respondents of the study are the administrator and staffs of the BulSU Supply Office. They were given a questionnaire and asked to evaluate the developed system.

Ten (10) IT experts and programmers were also asked to evaluate the developed website. Responses from the prospective clients were also considered by asking them to evaluate the system. Total number of respondents and evaluators are presented in Table 1.

Table 1. RESPONDENTS AND EVALUATORS OF THE STUDY

\begin{tabular}{ccc} 
& Frequency (N) & $\begin{array}{c}\text { Percentage } \\
(\%)\end{array}$ \\
\hline $\begin{array}{c}\text { BulSU Supply Office } \\
\text {-Administrator }\end{array}$ & 1 & $5 \%$ \\
\hline -Staff & 1 & $5 \%$ \\
\hline $\begin{array}{c}\text { IT Experts and } \\
\text { Programmers }\end{array}$ & 10 & $50 \%$ \\
\hline Prospective Clients & 8 & $40 \%$ \\
\hline Total & 20 & $100 \%$
\end{tabular}

Table 2 shows the summary of the computed mean of each software criteria as follows: functionality, accuracy, reliability, user-friendliness and security. The table also shows the level of acceptability of the developed website.

Table 2. IMPLEMENTATION ASSESSMENT OF THE BULSU ONLINE INVENTORY MANAGEMENT SYSTEM AND ITS LEVEL OF ACCEPTABILITY

\begin{tabular}{clcc} 
Software Criteria & $\begin{array}{c}\text { Computed } \\
\text { Mean }\end{array}$ & $\begin{array}{c}\text { Descriptive } \\
\text { Interpretation }\end{array}$ \\
\hline 1. & Functionality & 4.87 & $\begin{array}{c}\text { Strongly } \\
\text { Agree }\end{array}$ \\
\hline 2. & Accuracy & 4.91 & $\begin{array}{c}\text { Strongly } \\
\text { Agree }\end{array}$ \\
\hline 3. & Reliability & 4.83 & $\begin{array}{c}\text { Strongly } \\
\text { Agree }\end{array}$ \\
\hline 4. & User-Friendliness & 4.95 & $\begin{array}{c}\text { Strongly } \\
\text { Agree }\end{array}$ \\
\hline 5. & Security & 4.89 & $\begin{array}{c}\text { Strongly } \\
\text { Agree }\end{array}$ \\
\hline & Overall Mean & 4.89 & $\begin{array}{c}\text { Strongly } \\
\text { Agree }\end{array}$
\end{tabular}

4.60 - 5.00 Strongly Agree; 3.60 - 4.59 Agree; 2.60 - 3.59

Undecided; 1.60 - 2.59 Disagree; 1.0 - 1.59 Strongly

Disagree

Functionality registered a computed mean of 4.87 with a descriptive interpretation as "Strongly Agree". Accuracy on the other hand acquired 4.91 which is also interpreted as "Strongly Agree". Reliability acquired 4.83. A total mean of 4.95 was computed for the website user-friendliness which garnered the highest mean among the other criteria.

Lastly, Security feature registered 4.89 total mean. For the level of acceptability, all of the mentioned criteria interpreted as "Strongly Agree" by the respondents, IT experts and prospective client during the system evaluation and implementation.

\section{CONClusion}

Experiencing Digital Works through the Development of Online Inventory Management System for BuLSU Supply Office can be used for easy manipulation of data conveniently. It is designed to make the inventory transaction more efficient and effective which can be deployed online or using intranet infrastructure with the goal of making the transaction faster and lessen the use of manual recording of inventory items.

The Supply Office will be able to monitor and update all the inventory with less time and effort. The system includes adding and retrieving of records with security features. Room and property custodians of different Colleges and other departments just need to access their account thru online using their specified username and password.

\section{RECOMMENDATIONS}

Based on the results presented in the study, the following recommendations were drawn:

1. It is recommended that the developed Online Inventory Management System for BulSU Supply Office should be implemented and utilized in the University.

2. Maintenance of the developed website is recommended. The administrator should maintain and update all the inventory records, acquisitions and procurement.

3. A password recovery for the account users should be provided in case they have forgotten their account passwords. 


\section{ACKNOWLEDGMENT}

The proponent would like to express her gratitude and thanks to Bulacan State University Research Office for the kind support and help.

Thanks and appreciations also go to her family, her husband Erwin C. Castro, her children Ehrlyn Joy \& Ehrl Nehemiah B. Castro, her mother Mrs. Rosita D. Bondoc, also to her BulSU Graduate School Family, CICT family, her friends and relatives who supported her for the completion of this project and to the Almighty God who is always there to guide and help her.

\section{REFERENCES}

[1] Thomas Bronack, Inventory Management System, Standards and Procedures Manual, 2012.

[2] C. Drury, Management and Cost Accounting. London: International Housan Business Press. 1996

[3] A.N.Berger, and L.J. Mester, A study of bank efficiency taking into account risk-preferences. Journal of Banking \& Finance, 1997, 21.7. pp. 895-947.

[4] S.P. Desselle, and D.P. Zgarrick, Purchasing and Inventory Management, Pharmacy Management: Essentials for All Practice Settings 2nd ed., New York: McGraw-Hill Co., Inc, 2009, p. 383,

[5] Michael Blaha, James Rumbaugh. Object-Oriented Modeling and Design with UML, $2^{\text {nd }}$ edition. Prentice Hall, Upper Saddle River, N.J., 2005.

[6] Shirley Radack, "The System Development Life Cycle (SDLC)",http://csrc.nist.gov/publications /nistbul/april2009_ system-development-life-cycle. pdf.

[7] "Effective Practices for Modeling and Documentation" Agile modeling (AM) home page, Retrieved October 10, 2014 at www.agilemodeling.com, 2014.

[8] Blanchard, B. S., \& Fabrycky, W. J.(2006) "Systems Engineering And Analysis",(4th ed.) New Jersey: Prentice Hall. p.31

[9] Engstrom, S., Lierud, M., (2006): Experience Feedback in the Design Phase of Building Projects. Master's Thesis 2006:106. Department of Civil and Environmental Engineering, Division of Structural Engineering, Chalmers University of Technology, Goteborg, Sweden

[10] Flodstrom, Raquel (2006), A Framework for the Strategic Management of Information Technology. No.1272, IDA-EIS, Universitetet och Tekniska Hogs kolan i Linkoping. 